\title{
Államhatár-politikák az Európai Unióban és Magyarországon a globális koronavírus-válság kezdeti időszakában
}

\author{
Border policies in the European Union and Hungary in the initial \\ period of the global COVID-19 crisis \\ HAJDÚ ZOLTÁN, RÁCZ SZILÁRD
}

\begin{abstract}
HAJDÚ Zoltán: tudományos tanácsadó, Közgazdaság- és Regionális Tudományi Kutatóközpont, Regionális Kutatások Intézete, 7621 Pécs, Papnövelde u. 22.; hajdu@rkk.hu; https://orcid.org/0000-0003-2055-5962

RÁCZ Szilárd: tudományos munkatárs, Közgazdaság-és Regionális Tudományi Kutatóközpont, Regionális Kutatások Intézete, 7621 Pécs, Papnövelde u. 22.; szracz@rkk.hu; https://orcid.org/0000-0002-9397-2620
\end{abstract}

KULCSSZAVAK: határkutatás; határellenőrzés; koronavírus; határlezárás; EU; Magyarország

Zoltán HAJDÚ: scientific advisor, Institute for Regional Studies, Centre for Economic and Regional Studies, Papnövelde u. 22., H-7621 Pécs, Hungary; hajdu@rkk.hu; https://orcid.org/0000-00032055-5962

Szilárd RÁCZ: research fellow, Institute for Regional Studies, Centre for Economic and Regional Studies, Papnövelde u.22., H-7621 Pécs, Hungary; szracz@rkk.hu; https://orcid.org/ 0000-0002-9397-2620

KEYWORDS: border studies; border control; coronavirus; closed borders; EU; Hungary

\section{Bevezetés}

A globális világ ingatagsága a 2008-2009 közötti világméretű pénzügyi-gazdasági válságban vált rövid idő alatt „köztudottá”, majd a részben ahhoz kapcsolódó tömeges állam- és kontinensközi migráció 2010 után elmélyítette a válságtudatot. Donald Trump amerikai elnök a Kína elleni kereskedelmi és technológiai háború „,bejelentésével" minden tekintetben nemzeti hatalmi céllá tette a globalizáció elleni küzdelmet, az USA érdekeinek a védelmét. Az „Amerika az első” elnöki programkitűzés követőkre talált, rövid időn belül sok politikai elit számára saját országa lett az első és legfontosabb. (Egyes esetekben szinte kizárólagos.) A bezárkózás így a „nagypolitika” szintjén már a vírusjárvány előtt elkezdődött, szinte mindenre kiterjedően megjelent, annak csak része lett a „falak, kerítések építése”.

Az Európai Unióban jelentős kihívás a nemzeti érdekek és az integrált fejlödés szempontjainak összehangolása. Kutatásaink során az egyik fő kérdés annak

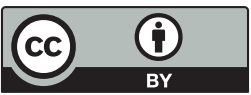


a megértése, hogy a nemzeti érdekek (állami egoizmusok) és az európai integrációs folyamatok közti feszültségek milyen módon formálták Magyarország és a szomszédos országok közti határokon átnyúló együttmüködések rendszerét különböző interakciós szinteken.

A KRTK Határkutató csoport korábbi munkája ${ }^{1}$ során már számos tanulmányban vizsgálta, hogy mi az államhatalom és az államhatár viszonya. Az ezekben leírt általános gondolatokat a jelenlegi helyzet tovább erősíti. Az utóbbi hetekben mindenki számára egyértelművé válhatott az, hogy az államhatáron, a határátkelőkön a központi államhatalom a korlátlan úr. A kapcsolatok megszakítása rövidtávon tömeges kényelmetlenség, közép- és hosszabb távon megalapozott bizalmatlanság.

A koronavírus Kínában ütötte fel a fejét (a titkolózások miatt pontosan nem lehet tudni, hogy mikor), s onnan indult el 2019 decemberétől. Rövid időn belül eljutott szinte minden kontinensre és országba. A vírus „zilált állapotban találta” az Európai Uniót, melynek legfontosabb „ügye” hosszú időn keresztül a Brexit és a külső tömeges migráció kérdésének a kezelése volt. A vírus megjelenésekor az új Parlament és az új Európai Bizottság még alig állt munkába. Több országban belpolitikai válságok voltak, kevéssé múködőképes kormányok tevékenykedtek.

Magyarország a tekintetben kivételt képezett, hogy a kormányzat erős parlamenti felhatalmazással rendelkezett a vírus megjelenésének időpontjában, ugyanakkor a járvány- és egészségügy személyi és technikai infrastruktúrája nem állt készen ilyen nagyságrendű feladatok ellátására. A vírus terjedésével párhuzamosan kellett megteremteni a vele szembeni védekezés és kezelésének személyi és közösségi eszközrendszerét.

Rövid elemzésünkben ${ }^{2}$ arra vállalkozunk, hogy bemutassuk, az élet minden területén rövid idő alatt mély válságokat eredményező járvány hogyan hatott az országok államhatár- és határellenőrzési politikájára, hogyan reagált a helyzet változásaira az EU, mit és hogyan szabályoztak a szomszédos országok, milyen lépéseket tett Magyarország. (A reakciók egyes esetekben pánikszerűek voltak, több országban előfordult, hogy egy napon belül is változtak a szabályok.)

\section{Az EU határpolitikai sajátosságai a járvány kirobbanásával párhuzamosan}

A tömeges migráció kihívásainak az EU egyes tagállamai a belső határok időszakos ellenőrzésével, sőt tényleges lezárásával kívántak gátat vetni 2015-től kezdve. A migrációval kapcsolatos tagállami és azokon belüli viták a nagypolitika szintjére emelték a határok ellenőrzésének kérdését. Az EU, az államközi kapcsolatok, s az államokon belüli viták részben „,határérzékenységet”, részben pedig „,valós határpszichózist" teremtettek.

Az EU egyes tagállamai körében a járvány olaszországi megjelenése, majd tömeges berobbanásának időszakától kezdve felvetődött a belső határellenőrzés 
visszaállításának az ügye. Nem alakult ki egységes ,járványpolitika” (még a legegyszerűbb szakmainak tűnő kérdésekben, hogy kell-e maszkot viselni, avagy sem), alapvető különbségek voltak a WHO, a vezető politikusok, sőt a járványügyi szakértők között is.

A belső határellenőrzés tekintetében Franciaország és Németország kulcshelyzetben volt a teljes szomszédsága irányába. Franciaország előbb Olaszország, majd Spanyolország felől érezte a vírusfenyegetettséget. Németország a „Schengeni határellenőrzési kódex” (2016/399 rendelete bázisán) a „közrend és a belső biztonság" fenntartása érdekében visszaállította a határellenőrzés rendszerét a déli határai mentén. Ezen belül engedélyezte az áruk és az ingázók mozgását.

Az Európai Bizottság és annak elnöke kifogásolta az egyoldalú döntéseket, $\mathrm{s}$ a belső határok korlátozásmentes nyitva tartása mellett foglalt állást március 13-án. A belső határellenőrzések visszaállítása a tagállamok részéről lépésre sarkallta az EU Bizottságát. Bár ellenezték a belső határok lezárását, az egységes belső piacot és a mozgások szabadságát féltették, a Bizottság elnöke, Ursula von der Leyen közreműködésével mégis olyan tervezet készült március közepén, amely 30 napra lezárná a külső határon a személyek mozgását, csak az EU polgárai léphetnének be, s mellettük csak orvosokat, nővéreket, kutatókat engednének be. Az áruszállítás szabadságát fenn kívánták tartani. Nem a Bizottság, s nem annak elnöke „zárta le” az EU külső határait március 17-én, hanem az Európai Tanács, a tagállamok állam- és kormányfőinek teljes egyetértésével. Az új helyzetben a külső határokon is minden körülmények között biztosítani kívánták az áruk szabad áramlásának a fenntartását.

A külföldön tartózkodó állampolgárok, a turisták, az úton lévők rendkívül kellemetlen helyzetbe kerültek a gyors döntések miatt. Nem egyszerüen anyagi nehézségek közé kerültek, hanem a bizonytalanság, sőt a kiszámíthatatlanság vált tömegek élményévé. A tagállami kormányok szervezték a külföldön rekedt állampolgáraik tömeges hazaszállítását.

Az Európai Bizottság az élelmiszerellátás biztosítása céljából március 30-án hivatalosan arra kérte a tagállami kormányokat, hogy engedélyezzék a mezőgazdasági idénymunkások és az egészségügyi dolgozók tömeges áramlását.

\section{Közvetlen szomszédságunk határpolitikai folyamatai}

Közvetlen államszomszédságunk többféle kétoldalú határsajátosságot hordoz. Az „EU - nem EU” tagállam megkülönböztetés mellett az adott folyamatok szempontjából fontos „a Schengen - nem Schengen” reláció is.

Az EU, a szomszédos országok döntései minden irányban és nagyon sokféle tartalommal megjelentek. A tranzitutasok, a turisták, az ingázók egyaránt kiszolgáltatottakká, szenvedő alanyokká váltak rövid időre. 
A korábbi napi ingázók szinte egyik óráról a másikra lehetetlen helyzetbe kerültek a magyar és a szomszédos országok rendelkezései következtében. Nem csak az ingázó munkaerő, de a foglalkoztatójuk is súlyos helyzetbe került. (A Suzuki esztergomi gyárának teljes átszervezéssel kellett pótolnia a szlovákiai „kizárt" munkaerőt.) Magyar kezdeményezésre néhány napon belül megoldódott a szlovákiai, ausztriai, romániai, horvátországi határon átnyúló napi ingázók problémája, de több esetben jelentős kerülőkre kényszerültek, a napi időveszteségek nagyok voltak. Általában a kijelölt határátkelők 30 kilométeres körzetéből engedélyezték a napi ingázást.

\section{Ausztria}

Az osztrák-magyar határ ellenőrzésének kérdésköre, mely a vasfüggöny leomlásától valamilyen szinten folyamatosan jelen volt az osztrák oldalon, a 2015-ös migrációs válság időszakában került ismét a politikai viták homlokterébe. Ausztria mint „régi EU- és Schengen-zóna tag” alkalmazta az EU-jogot, s a schengeni határrezsimet.

A „vírusválság” időszakában természetes módon Ausztria is részese volt az „EU-jogalkotásnak”, ugyanakkor megjelenítette saját érdekeit és elképzeléseit is. Ausztria - lényegében Németországgal párhuzamosan - előbb korlátozta a határforgalmat (március 13.), majd az EU egyeztetett döntése után teljesen lezárta saját határait. Március 13-án csak három magyarországi határátkelőn (Hegyeshalom, Rábafüzes, Sopron) tette lehetővé a nemzetközi teherforgalmat. A döntés nem csak a határátkelőket érintette, hanem azt is jelentette, hogy a „zöldhatár átlépése jogellenessé vált", szabálysértési eljárást vont maga után.

Ausztria, s főleg Tirol síterepei és szállodái az európai kiterjedésủ járvány egyik „gócpontjának szerepét” töltötték be. (Ischgl település és egy bárja Európaszerte hírhedtté vált.) A tiroli turisztikai központok kiürültek, s csaknem ezer magyar alkalmazott vált hirtelen munkanélkülivé. (Március 16-án karanténba helyezték Tirolt.) Egy részük azonnal hazaindult, mintegy 500 fó megkésve indulva „belefutott” a kihirdetett határzárba.

Március 16-17. után a magyar-osztrák határon a rendszerváltás és a migrációs válság óta nem tapasztalt folyamatok bontakoztak ki, illetve az egyének számára súlyos állapotok alakultak ki. Az Ausztriába naponta ingázó magyarok egy része (főként a biztosnak tűnő munkahellyel rendelkezők) úgy döntött a határ teljes lezárásától való félelmében, hogy kinn marad és ott várja meg a fejleményeket, más részük hazautazott.

\section{Szlovákia}

Szlovákia március 13-tól visszaállította a határellenőrzést, ideiglenes rendszabályként csak a szlovák állampolgárok léphettek be az országba. Az áruszállítást 
nem korlátozták. Az ingázók mozgása lehetetlenné vált napokra. Ez elemi gondot jelentett nem csak az egyének, családok életében, de a magyarországi foglalkoztatók számára is. Az esztergomi Suzuki és a győri Audi-gyár munkarend-átszervezésre kényszerült már a leállásról szóló döntés előtt.

A határon át történő személyforgalom szabályozásában ezen a határszakaszon is rövid időn belül változások történtek. Szlovákia húsvét előtt külön rendszabályokat léptetett életbe, a belső és a határokon átnyúló mozgások tekintetében is. Április 8-10. között csak a következő átkelési pontok maradtak nyitva: Rajka, Vámosszabadi, Komárom, Esztergom, Parassapuszta, Balassagyarmat, Salgótarján, Bánréve, Tornyosnémeti, Sátoraljaújhely.

\section{Ukrajna}

Az ország igazi EU-külső szomszédként a legbonyolultabb helyzetbe került. Részben az EU, részben a magyar rendelkezések nehezítették meg a nyugati országokban és Csehországban dolgozó ukrajnai vendégmunkások hazatérését. Ukrajna első lépésként a március 15-29. közötti időszakra kiterjedően lezárta határait a külföldiek előtt. A magyar-osztrák határon a határzárak miatt feltorlódott ukránokat Magyarország humanitárius folyosón engedte át.

Időnként az ukrán döntések sem segítették a vendégmunkások tömege helyzetének megoldását, hiszen bevezették azt (március 26.), hogy a saját állampolgáraikat sem engedték be. (Ennél durvább döntés az időszakban csak Bolíviában született, ahol - belpolitikai okoknál fogva - a Chiléből hazatérni vágyó állampolgáraikat könnygázzal és gumilövedékekkel tartották távol a hazájuktól.) Az ukrán elnök azzal indokolta - a rövid ideig fenntartható - döntését, hogy választania kellett a járványhelyzet miatt a még külföldön maradt ukránok és az otthon élő mintegy 40 millió lakos biztonsága között.

Április 6-án lényegi változások léptek hatályba az ukrán kormány döntése következtében a közös határon. Megszűnt a gyalogos, kerékpáros, mikrobuszos, buszos belépés lehetősége az átkelőkön. Csak saját tulajdonú személygépkocsival engedélyezik a belépést. A kisebb határátkelőkön való forgalom lehetőségét megszüntették a közös határon, csak Záhonynál lehet be- és kilépni a magyar szakaszon ukrán relációban. A vasúti személyforgalom felfüggesztésre került a két ország között.

\section{Románia}

A román állampolgárok tömegeit érintette a munkahelyük és életlehetőségük elvesztése a nyugati országokban. Tömegesen indultak meg gépkocsikon haza. A magyar-osztrák határra érve szembe találták magukat a határok lezárásával. Március 17-én Románia humanitárius folyosó megnyitását kérte. Magyarország rövid időn belül megnyitotta a humanitárius folyosót a román és bolgár állam- 
polgárok számára, akik kijelölt útvonalon érkeztek a román átkelőhelyekre, s hagyhatták el Magyarország területét.

A nagytérségi, határokon keresztüli vonulás után kistérségi kérdések kerültek elötérbe, a határon átnyúló ingázás kérdése. Néhány napos bizonytalanság után a VIII. román katonai rendelet április 9-én rendezte a magyar-román határon átnyúló ingázás romániai helyzetét. Az ingázónak - ha egészséges - nem kell karanténba, vagy lakhely-elkülönülésbe vonulnia a munkába járása során. A rendelet területi hatálya azokra vonatkozik, akik bármely határátkelőtől 30 kilométeren belül élnek, s legalább hetente egyszer ingáznak a lakóhelyük és a munkahelyük között. A határok lezárása időszakában az ingázók csak a három (Létavértes-Székelyhíd, Méhkerék-Nagyszalonta, Nyírábrány-Érmihályfalva) kijelölt átkelőn keresztül mozoghattak, hosszú kerülőkkel és időveszteséggel. Április 10-től megnyílt számukra a Nagycsanád-Kiszombor, Nagylak-Nagylak, Battonya-Tornya, Gyula-Gyulavarsád, Átánd-Bors, Vállaj-Csanálos, Csengersima-Pete átkelési lehetőség is.

A német mezőgazdaság munkaerő-szükséglete (a német mezőgazdasági miniszter szerint az ország mezőgazdasága áprilisra 40 ezer, májusra újabb 40 ezer fó idényfoglalkoztatott munkaerőt igényel) jelentős szívóhatást gyakorol ezen feltételek között is az olcsó kelet-európai munkásokra, az állásukat frissen elvesztettekre. Először a lengyel és a romániai munkaerő „mozdult meg” lényegében a járvány közepén. Az adott határzárak és bizonytalanságok között charter repülögépekkel (szinte légihidakkal) szállítják a toborzott embereket. Kolozsváron botrányba fulladt április 9-én a repülőtéren mintegy 1 500-2 000 ember megjelenése. A toborzás jogszerű volt, a lebonyolítás módjából - a járványügyi előírások tömeges megsértéséből - azonban büntetőeljárás lett.

Ausztria bejelentette, hogy az egészségügyben és a szociális ellátás területén kialakult nagyfogú szakemberhiány felszámolására „zárt irányvonatokat” kíván szervezni Románia és Bécs között. A szerelvények magyarországi megállások nélkül, éjszaka szállítanák át a romániai munkaerőt.

\section{Szerbia}

2015 óta a magyar-szerb határon folyamatosan „határhelyzet van”. A magyar műszaki határzár megépítése ténylegesen a határon átnyúló migrációs mozgások megakadályozását jelentette Magyarország felé. A kihívás folyamatos maradt, de részben szerb közremüködéssel sikerült megakadályozni a 2015-ös állapotok kialakulását.

A koronavírus megjelenésével és terjedésével párhuzamosan Szerbia is lezárta határait a személyforgalom előtt, mindössze három (Hercegszántó, Röszke, Tompa) határátkelőt hagyott nyitva a teherforgalom számára. Március 20-ra a teherforgalom bedugult, két-három napos várakozási időt igényelt a feltorlódott kamionok átkelése a határon. 
A vajdasági magyar politikusok kezdeményezésére Magyarország Szerbiával is ki kívánja alakítani az ingázók „szabad mozgásának” feltételeit, de ez időigényesebb folyamat, mint ahogy a többi szomszédunk irányában megtörtént.

A magyar kormányzat nem járult hozzá, hogy - a román és ukrán megoldáshoz hasonlóan - humanitárius folyosót nyisson a főleg Olaszországból és részben a német nyelvterületről hazatérő szerbiai vendégmunkások számára. Ezzel mintegy rákényszerítették Szlovéniát, Horvátországot és Szerbiát az ügyben való együttmüködésre. (A kérdést meg tudták oldani.)

\section{Horvátország}

A magyar-horvát „határhelyzet” alapvetően az európai uniós döntéseknek megfelelően alakult. Mikrotérségi szinten kellett a két kormánynak sajátos megoldást keresni. Március végén a muraközi horvát szőlősgazdák azt kérték a két állam illetékes szerveitől, hogy tegyék lehetővé számukra a Magyarországon fekvő szőlőterületeik műveléséhez szükséges oda-vissza átkelést (ingázást). A két külügyminisztérium rövid időn belül megállapodott az egyéni mozgások szabályozásáról. A két ország közötti mind a hét határátkelőn lehetővé vált a mozgás.

\section{Szlovénia}

A viszonylag „csendes” szlovén határon Magyarország lépett először, március 13-án ideiglenesen - az osztrák szakasszal egy időben - visszaállította a határellenőrzést. Rövid időre leállt a személy- és teherforgalom, csak magyar állampolgárokat engedtek belépni az ország területére. A nemzetközi határforgalom számára Rédics, Tornyiszentmiklós került kijelölésre. A magyar és szlovén állampolgárok számára Pince is használható maradt. Minden járművet és személyt megállítottak, s nyilatkoztattak arról, hogy mely területről érkezett a határra. Április 2-án újra megnyílt a két ország állampolgárai számára a bajánsenyei és a kétvölgyi határátkelő is.

\section{Magyarország}

A különböző nemzetközi és hazai híradások arról számoltak be 2020. február 24-én, hogy az első pozitív teszteredményt mutató magyar állampolgár a Japán főváros mellett karanténba helyezett Diamond Princess óceánjárón dolgozó magyar lett.

A koronavírus „igazoltan” 2020. március 4-én jelent meg Magyarországon, illetve az egészségügy számára. Az első két magyarországi beteg Iránból visszatért, Magyarországon legálisan tartózkodó egyetemi hallgató lett. A két hallgató feltehetően február 22-én érkezett a Liszt Ferenc Repülőtérre, amikor Európában 
„a víruskérdés” már megjelent. Nem kerültek hatósági karanténba, lényegében rájuk volt bízva, hogy távol tartják-e magukat a különböző közösségektől, illetve csoportos rendezvényektől. (Nem tartották távol magukat.)

Nem tett jót a helyzet kezelésének, hogy a nyomtatott és főleg a sokszínű elektronikus magyar sajtó egy része nem tette világossá az első pillanattól kezdve, hogy nem „illegális migránsokról” van szó, hanem egy részük ugyan nem direkt módon megfogalmazva, de ezt igyekezett érzékeltetni.

Március 11-én a kormány járványügyi veszélyhelyzetet hirdetett ki, beutazási korlátozásokat vezetett be a leginkább „fertőzöttnek” tekintett országokból.

2020. március 15-én meghalt az első magyar koronavírusban szenvedő beteg. Elindult a folyamat új módon és új dimenzióban való kezelése.

Magyarország március 17-én rendelte el a járványügyi hatósági határzárat. Nem adtak a rendelkezés tudomásul vételére elég időt a külföldön dolgozó magyar, és a tranzitban érdekelt szomszédos országok állampolgárainak a felkészülésre, az utazásuk megszervezésére. A rendelkezések életbe lépése után több ezer ember torlódott össze Hegyeshalomnál, több kilométeres kocsisor, több órás várakozás várt a belépni szándékozó magyarokra is.

Az ausztriai munkahelyek tömeges elvesztése, a határzár a határ magyar oldalán is sajátos folyamatokat indított el. Sopron, Kőszeg, Szombathely jelenlévő népessége jelentősen csökkent az ingázók tömeges elutazásával. Csökkenő ártendenciák alakultak ki az albérleti piacokon.

Március 28-tól a kormány kijárási korlátozásokat rendelt el április 11-ig, majd határozatlan időre. Március 30-án a parlamenti többség határozatlan időtartamra felhatalmazta a kormányt a rendeleti úton való kormányzásra.

Április elejére néhány, a tömeges idegenforgalomra berendezkedett település vezetése elkezdte korlátozni az „idegenek” (nem helyi lakosok) településre érkezését. Április 9-től már jogszabályi lehetőséget is teremtett erre a kormány, több település élt a „bezárkózás” lehetőségével. A félelem „másoktól” így elérte az országlakosokat is, különösen a budapestieket tették felelőssé azért, hogy a különböző korlátozások ellenére tömegesen utaztak a Balatonra, a Duna-kanyarba stb. Hosszú távon nehéz megítélni ennek a helyzetnek a hatásait.

A településen belüli lezárások a kirándulóhelyeket érintik, ahol a helyben lakók is sajátos időbeni korlátozásban „részesülnek”.

Bár a tavasz nem igazán turisztikai főszezon, de a határzár életbe lépésekor mintegy 10 ezer magyar tartózkodott a világ különböző részein magán- és rövid hivatalos úton. Szijjártó Péter április 8-i sajtónyilatkozata szerint eddig az időponting 8200 magyarországi lakóhelyű magyar állampolgár hazahozatalában segítettek a konzuli szolgálatok és a KKM. A külügyminiszter szerint „Magyarország modern kori története legnagyobb hazatérési akciója” volt ez. (Egészében véve 10 ezer magyar állampolgár hazaszállítása történt meg a határok lezárása után.) 


\section{Összegzés}

A koronavírus tragikus hatásai nem csak a tömeges megbetegedések és halálozások tekintetében jelentek meg, de hihetetlenül rövid idő alatt romboltak a gazdaság, a társadalom, az oktatás, a kereskedelem stb. területén egyaránt.

A vírus terjedésének korlátozási szándéka (senki nem gondolta, hogy teljesen meg lehet akadályozni a mozgását) az államhatárok ellenőrzése, sőt védelme oldaláról is megjelent. Az egyéni bezárkózások után az EU külső határainak a lezárásához is elvezettek, legalábbis a személyi mozgások tekintetében. A gyors, felkészülésre, alkalmazkodásra lényegében időt nem adó döntések tömegeket hoztak nagyon kellemetlen, kényelmetlen, sőt veszélyes helyzetbe.

A gazdaság működése és a lakosság ellátása érdekében a tömeges szárazföldi árufuvarozás lehetősége a legtöbb határon fennmaradt. (Az Európai Unióban mintegy 3 millió ember érintett a távolsági teherszállításban.) Kamionvezetők tízezrei voltak és vannak úton Európában, akik - minden ténylegesen bevezetett és betartott óvintézkedések ellenére - nem csak önmagukra nézve jelentenek kockázatot, de szélesebb értelemben a lakosság számára is. (A kamionosok a járvány fokozódásával „hősökből szinte ellenségekké váltak”.)

A járvány hosszú távú hatásai még nem mérhetők fel, de az biztos, hogy a tömeges határokon átnyúló mozgásokat (történjen bármilyen közlekedési eszközön a luxus óceánjárótól a mikrotérségi gyalogos forgalomig) befolyásolni fogja a jövőben. A tragédia jelenlegi szintjén is mindenkinek újra kell gondolnia lehetőségeit és szükségleteit. Az újragondolásban nem a profit, nem az élmény maximalizálása, hanem a biztonságra való törekvés fog vezérelvvé válni.

Európa politikai és tudományos közössége mintegy két évtizeden keresztül a „,határok megszűnéséről”, „határtalan Európáról”, a „határok virtualizálódásáról” stb. beszélt, értekezett, tervezett. Egy súlyos járvány szinte „pillanatok alatt” negligálta ezeket a törekvéseket. Az európai és tagállami döntések a valóságban „légiesítették” - legalábbis egy időre - az államhatárokon átnyúló, különböző jellegü regionális szerveződések munkáját. A központi államhatalmak Európa-szerte főszereplővé váltak az államhatárokon.

\section{Jegyzetek}

1 A jelenlegi kutatás átfogó előzménye az OTKA NN114468 számú Változás és folytonosság a magyar térképzetekben: nemzet, területiség, fejlesztés és határpolitika című, 2015-2019 között zajlott projekt. Honlap: http://nyilvanos.otka-palyazat.hu/index.php?menuid=930\&num=114468\& A kézirat lezárásának időpontja: 2020. április 14.

A kézirat korábbi változata, mint a KRTK Regionális Kutatások Intézete koronavírussal összefüggő műhelytanulmánya, Államhatár-politikák az Európai Unióban és Magyarországon a globális COVID-19 vírusválság kezdeti időszakában címmel jelent meg, elérhetősége: http:// www.docs.rkk.hu/rkkweb/Hajdu_Racz_hatar_virus_2020.pdf 